\title{
Survival of ground beetles (Coleoptera: Carabidae) submerged during floods: Field and laboratory studies
}

\author{
Felix N. KOLESNIKOV ${ }^{1}$, AREVIK N. KARAMYAN ${ }^{2}$ and W. WyatT HOBACK ${ }^{3}$ \\ ${ }^{1}$ Bryansk State Agricultural Academy, Kokino, Vigonichy district, Bryansk region, 243365, Russian Federation; \\ e-mail: f.kolesnikov@mail.ru \\ ${ }^{2}$ Yerevan State University, Alex Manoogian Street 1, Yerevan 375049, Republic of Armenia \\ ${ }^{3}$ University of Nebraska at Kearney, 905 West $25^{\text {th }}$ Street, Kearney, Nebraska, 68849, USA
}

Key words. Carabidae, survival time, submergence, flooding, hypoxic conditions

\begin{abstract}
Field and laboratory experiments were conducted to assess the time ground beetles (Coleoptera: Carabidae) survive during actual and simulated flood conditions. The effects of three variants of potential flood conditions were tested: (1) beetles trapped on the surface of flood water; (2) beetles trapped in air pockets; (3) submersion of beetles in flood water without access to air. Ground beetles trapped on the surface of water survived more than two weeks (Carabus granulatus - up to 16 days; Oxypselaphus obscurus - up to 22 days). Carabus granulatus in simulated hibernation chambers that had air-pockets also survived for 15 days. The time for which ground beetles submerged without access to air survived differed significantly among species and was affected by season. They survived longest in mid-spring and late-autumn when water temperature is low. In mid-spring, survival times for $C$. granulatus and Platynus assimilis were 12 days and 9 days, respectively. During late summer and early autumn all species survived for a shorter period of time. In August, at least half of the individuals tested were dead after three days of immersion (water temperature $\left.16-18^{\circ} \mathrm{C}\right)$. Removal of both of the elytra of adult of $C$. granulatus resulted in them surviving immersion for a shorter period, which indicates that air stored in the sub-elytral cavity is used to prolong the period they can survive immersion. The results of these experiments broaden the knowledge of how adult beetles survive seasonal flooding and are able to persist in floodplain habitats.
\end{abstract}

\section{INTRODUCTION}

Floodplains are exposed to periodic floods and organisms inhabiting floodplains are adapted to survive these conditions. Several methods of surviving flooding are described for insects: (1) individuals stay near the water edge and move when the water level changes (Irmler, 1979; Brust et al., 2006); (2) some species move up on to the non-inundated trunks and into the crowns of trees (Adis, 1982; Amorim et al., 1997); (3) others disperse to adjacent, non-inundated habitats on floodplains (Zerm \& Adis, 2001; Andersen, 2005); (4) and finally, some species survive floods while staying in the inundated habitat (Tamm, 1984, 1986; Adis, 1986; Forschler \& Henderson, 1995; Hoback et al., 1998, 2000; Zerm \& Adis, 2001; Zerm et al., 2004; Brust et al., 2005).

Insects survive immersion by decreasing their metabolic rate, respiring with a physical gill and/or switching to anaerobic metabolism (Hochachka et al., 1993; Wegener, 1993; Hoback \& Stanley, 2001; Zerm et al., 2004). However, not all insects, even within the same genus, are adapted to survive immersion to the same extent (Hoback et al., 2002; Brust \& Hoback, 2009). Moreover, previous studies have exposed adult and larval insects to "worstcase scenarios" of being completely immersed in severely hypoxic water to simulate conditions associated with flooded soils (Baumgartl et al., 1994). However, a number of insect taxa that stay in flooded habitats are not exposed directly to flood water and survive by trapping air in burrows as observed in mangrove ants (Nielson \&
Christian, 2007) and intertidal rove beetles (Wyatt, 1986) or by floating to the water's surface.

In this study, survival of ground beetles (Coleoptera: Carabidae) was assessed for three conditions: adult beetles trapped (1) on the surface of flood water, (2) in a submerged air pocket and (3) submerged without access to air. In addition, the effects of removal of both elytra on survival were assessed for one species, Carabus granulatus.

\section{MATERIAL AND METHODS}

\section{Study sites}

The individuals of ground beetles used in this study were collected from the floodplains of the Desna and Nerussa Rivers (Bryansk region, Russian Federation) during 2009-2011. The study site at the Nerussa River $\left(52^{\circ} 23^{\prime} 56^{\prime \prime} \mathrm{N}, 34^{\circ} 7^{\prime} 16^{\prime \prime} \mathrm{E}\right)$ is part of a sandy river bar covered with sparse vegetation (Xanthium albinum, Polygonum persicaria, Corispermum orientale). The shoreline was densely covered with grass and separate individual trees of Salix viminalis and $S$. triandra. The study site at the Desna River $\left(53^{\circ} 11^{\prime} 59^{\prime \prime} \mathrm{N}, 34^{\circ} 20^{\prime} 31^{\prime \prime} \mathrm{E}\right)$ is a natural levee on which the dominant vegetation consisted of Salix alba, Acer negundo and Ulmus laevis, and Urtica dioica, Glechoma hederacea and Impatiens noli-tangere dominated the herbaceous layer.

\section{Species and methods of collection}

The present study examined 11 species of ground beetles from these floodplains $(\mathrm{DRf}=$ Desna River floodplain; $\mathrm{NRf}=$ Nerussa River floodplain; $s b=$ spring breeder; $a b=$ autumn breeder). 


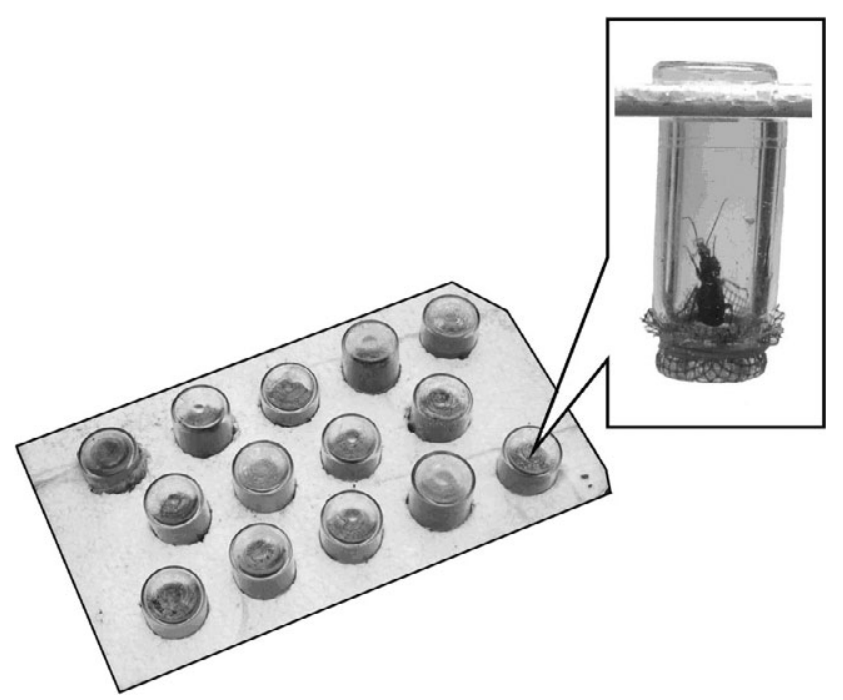

Fig. 1. Floating plate with glass tubes containing beetles that was used to submerge beetles in flood water.

\section{Omophron limbatum (NRf; sb) \\ Carabus granulatus (DRf; sb) \\ Dyschirius arenosus (NRf; sb) \\ Bembidion dentellum (DRf; sb) \\ Patrobus atrorufus (DRf; ab) \\ Pterostichus minor (DRf; sb) \\ Pterostichus aethiops (DRf; sb) \\ Agonum fuliginosum (DRf; sb) \\ Platynus assimilis (DRf; sb) \\ Oxypselaphus obscurus (DRf; sb) \\ Amara fulva (NRf; ab)}

On the Desna River floodplain spring breeding species were collected from under the bark of fallen trees and rotten wood. Most of the beetles were collected during three days in the last week of March when spring floods begin to inundate the study area. After collection, adults were maintained in perforated plastic boxes filled with shredded rotten wood that were buried in the field for three days until the experiment started. Some individuals of $C$. granulatus were taken from hibernating sites in November. On the Nerussa River floodplain all species were collected at the beginning of August when summer floods can occur. $O$. limbatum individuals were collected by pulling up riverine grasses and shaking the beetles off their roots. $D$. arenosus adults were collected by loosening (digging in?) sand in the littoral zone. Autumn breeding species ( $P$. atrorufus, A. fulva), both on the Desna and Nerussa floodplains, were collected by pitfall trapping. The species collected in summer were tested one day after collection.

\section{Experiments}

To study the survival of ground beetles trapped on a water surface, individuals (one by one) were put into $200 \mathrm{ml}$ plastic vessels filled with river water. These vessels in turn were put into larger vessels. The experiment was conducted under laboratory conditions. Water temperature was maintained between 6 and $9{ }^{\circ} \mathrm{C}$ (similar to natural conditions) by adding ice to the larger outer vessels. Beetle survival was recorded each day.

The survival of ground beetles submerged in air pockets was tested in April by placing individual carabid adults into $10 \mathrm{ml}$ glass tubes, which simulate a hibernation chamber. The opening of the tube was $12 \mathrm{~mm}$ in diameter and was covered with a plastic screen with $1.5 \mathrm{~mm}$ openings. These tubes were inserted into a foam plate, which was floated on the surface of flood

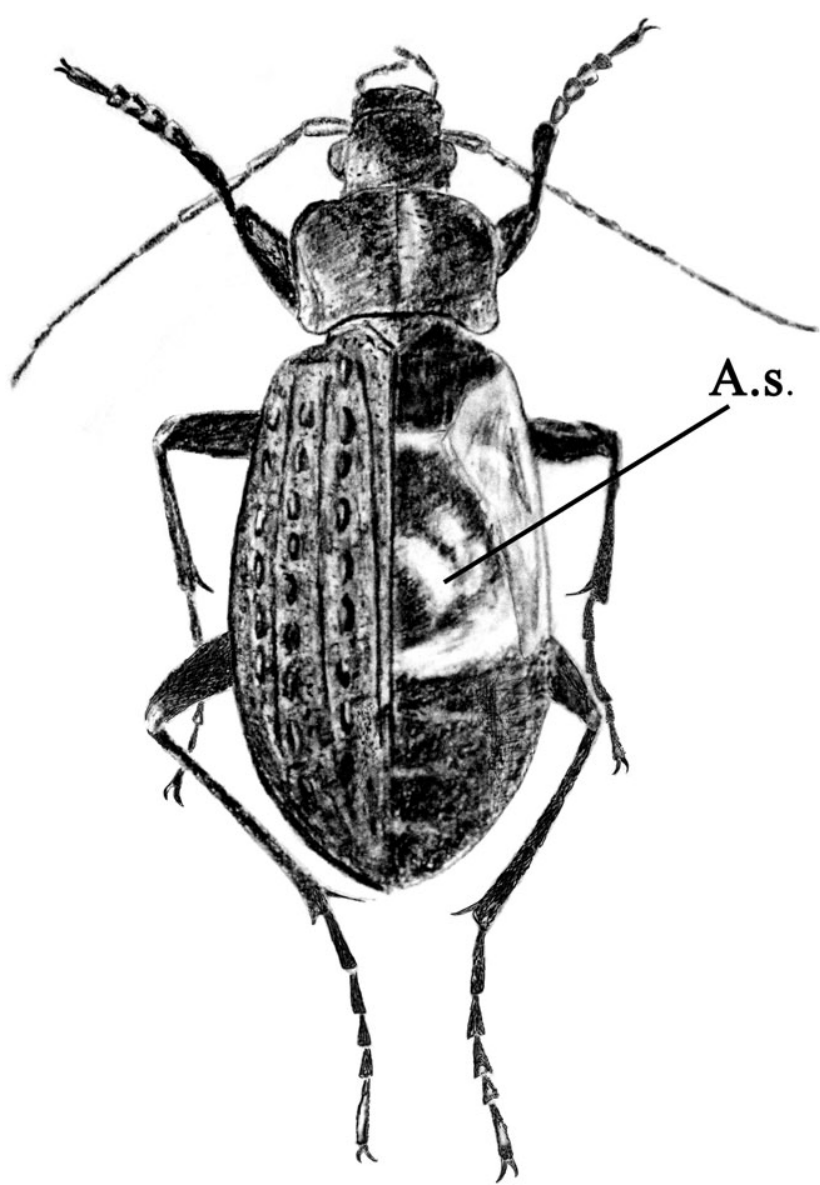

Fig. 2. A submerged Carabus granulatus with its right elytron removed to reveal the air store under the elytron. A.s. - air store.

water so that the openings covered with mesh were under the water (Fig. 1). This experiment was conducted in the field and the survival of the beetles was recorded every three days.

To study the survival of adult carabids submerged without access to air, beetles were individually immobilized by submerging in cold water $\left(4^{\circ} \mathrm{C}\right)$ and divided into two groups. The first group of beetles was placed in glass tubes closed with gauze and the second group in tubes filled with shredded rotten wood (see below). The tubes were then submerged at a depth of $20-30 \mathrm{~cm}$ and air bubbles dislodged by gentle tapping. At the end of the experimental period beetles were allowed to recover on a moist substrate and were checked for movement after $24 \mathrm{~h}$. This experiment was conducted on different species, in different seasons and at different temperatures. During spring tubes, each containing an individual carabid, were placed at the bottom of the temporary ponds that form in local depressions in the Desna River floodplain during floods. During summer and autumn, individuals were submerged directly in the river. The same experimental procedures were conducted in the laboratory in April with the water temperature maintained at $22^{\circ} \mathrm{C}$. Beetle survival was recorded each day.

To test the effects of hibernation on beetle survival, plastic jars $(25 \times 16 \times 6 \mathrm{~cm})$ were packed with finely shredded rotten wood. Prior to filling with wood, adult beetles were individually immobilized in cold $\left(4^{\circ} \mathrm{C}\right)$ water and placed in the jars. The jars were then filled with cold water and the wood shavings were pressed to remove trapped air. Survival of beetles was recorded every three days. 
TABLE 1. Survival of ground beetles submerged without access to air for from 1 to 12 days under field conditions. Results are presented as individuals alive after days submerged.

\begin{tabular}{|c|c|c|c|c|c|c|c|c|c|c|c|c|c|}
\hline \multirow{2}{*}{ Month } & \multirow{2}{*}{ Species } & \multirow{2}{*}{$\begin{array}{l}\text { Initial no. } \\
\text { of beetles }\end{array}$} & \multicolumn{11}{|c|}{ Days of exposure } \\
\hline & & & 1 & 2 & 3 & 4 & 5 & 6 & 7 & 8 & 9 & 10 & 12 \\
\hline \multirow[t]{2}{*}{ April } & Carabus granulatus & 7 & & 7 & & 7 & & 6 & & 7 & & 7 & 2 \\
\hline & C. granulatus (in wood) & 8 & & & 7 & & & 6 & & & 6 & & 2 \\
\hline August & C. granulatus & 8 & 8 & 8 & 4 & & & & & & & & \\
\hline September & C. granulatus & 10 & & 10 & & 10 & & 9 & & & & 0 & \\
\hline October & C. granulatus & 15 & & & & & 14 & & & & & 15 & \\
\hline \multirow{2}{*}{ April } & Platynus assimilis & 10 & & 10 & & 9 & & 10 & & 9 & & 1 & \\
\hline & P. assimilis (in wood) & 10 & & & 7 & & & 4 & & & 1 & & 0 \\
\hline August & P. assimilis & 10 & 10 & 9 & 6 & & & & & & & & \\
\hline September & P. assimilis & 10 & & 10 & & 10 & & 2 & & & & & \\
\hline October & P. assimilis & 10 & & & & & 10 & & & & & 10 & \\
\hline September & Bembidion dentellum & 10 & 10 & 8 & 1 & & & & & & & & \\
\hline October & B. dentellum & 10 & & & & & 10 & & & & & 10 & \\
\hline September & Oxypselaphus obscurus & 10 & 0 & & & & & & & & & & \\
\hline October & O. obscurus & 10 & 10 & & 0 & & & & & & & & \\
\hline November & O. obscurus & 8 & & & 8 & & & 4 & 0 & & & & \\
\hline August & Amara fulva & 10 & 4 & 1 & 0 & & & & & & & & \\
\hline August & Omophron limbatum & 15 & 15 & 1 & 1 & & & & & & & & \\
\hline August & Dyschirius arenosus & 10 & 7 & 0 & 0 & & & & & & & & \\
\hline September & Patrobus atrorufus & 10 & 0 & & & & & & & & & & \\
\hline September & Pterostichus aethiops & 10 & 10 & 10 & 10 & & & & & & & & \\
\hline October & Agonum fuliginosum & 20 & & & 20 & & & 20 & & & 10 & & \\
\hline November & Pterostichus minor & 6 & & & 3 & & & 0 & & & & & \\
\hline
\end{tabular}

To determine if $C$. granulatus L. can use a physical gill located under its elytra (the subelytral cavity) (Fig. 2), field collected individuals were divided into two groups. Beetles were first immersed in cold water for one hour. The control group was tested with their elytra intact whereas those of the second group had been removed using scissors. After manipulation, ten beetles of each group were placed in $200 \mathrm{ml}$ vessels and submerged in the river $\left(30 \mathrm{~cm}\right.$ depth, water temperature $\left.6-8^{\circ} \mathrm{C}\right)$. The survival of these beetles was recorded after $4,8,12$ and 16 days.

The same experiment was repeated under laboratory conditions (water temperature $4^{\circ} \mathrm{C}$ ). Pairs of C. granulatus (previously immobilized by submergence) were placed in $10 \mathrm{ml}$ tubes, which were submerged in $700 \mathrm{ml}$ jars filled with water. Once per day, the water in the larger jar was replaced. Survival was recorded after 8,12 and 16 days.

Where sample size and survival data allowed, percentage mortality was analyzed using Toxstat 3.4 (Western Ecosystems Technology, Inc., Cheyenne, WY). Probit analysis was used to calculate time to $50 \%$ mortality $\left(\mathrm{LT}_{50}\right)$ and $95 \%$ confidence intervals. Significant differences were judged as those with nonoverlapping confidence intervals.

\section{RESULTS}

\section{Survival on the water surface}

Most of the ground beetles, C. granulatus L. and $O$. obscurus Hbst, placed on a water surface were still alive a week and some individuals of both species alive more than 2 weeks later. Calculated times to $50 \%$ mortality ( \pm $95 \%$ C.I. $)$ were similar $(12.97 \pm 1.1$ versus $13.46 \pm 1.22$ days, respectively). Dead individuals usually sank however, several dead individuals of $O$. obscurus remained on the water surface for the period of observation.

\section{Survival of submerged beetles in air pockets}

Adults of $C$. granulatus overwinter in chambers formed in soil or rotten wood and when submerged the air in these chambers could slowly become hypoxic or potentially serve as a physical gill, exchanging oxygen with the surrounding water. Approximately one third of the individuals tested survived more than 15 days in the simulated hibernacula (Table 2). Calculated time to 50\% mortality ( $\pm 95 \%$ C.I.) was $12.74 \pm 2.2$ days.

\section{Survival of ground beetles submerged without access to air}

Survival of ground beetles submerged without access to air was studied both in laboratory and field conditions. A total of 11 species were tested in different seasons. Survival times differed among species and within species across seasons. For all species tested, the longest survival times were recorded in mid-spring and late-autumn when water temperatures were less than $10^{\circ} \mathrm{C}$ (Table 1). In trials conducted in mid-spring, C. granulatus survived up to 12 days and one adult of $P$. assimilis survived 10 days. During late summer and early autumn, survival times for most species tested were three days or less. In August, when water temperatures were between 16 and $18^{\circ} \mathrm{C}$ most individuals of the five species tested were dead after two days of submergence (Table 1).

In September, when water temperatures cooled to around $10^{\circ} \mathrm{C}$, survival times differed between species with individuals of $C$. granulatus and $P$. assimilis surviving six days of submergence, while $B$. dentellum, $O$. obscurus and $P$. atrorufus survived no more than three days. In late autumn (October-November), survival times for most species were greater than 10 days; however, half 
TABLE 2. Survival rate of Carabus granulatus submerged in air pockets under field conditions in April when water temperature were $6-9^{\circ} \mathrm{C}$ and of individuals after the ablation of their elytra submerged for 3 to 17 days in November in water at $6-8^{\circ} \mathrm{C}$ in the laboratory and the field. Results are presented as individuals alive after days submerged.

\begin{tabular}{lccccccccc}
\hline & $\begin{array}{c}\text { Initial no. } \\
\text { of beetles }\end{array}$ & 3 & 4 & 6 & 8 & 9 & 12 & 15 & 16 \\
\hline Air pocket & 8 & 8 & & 7 & & 8 & 3 & 3 & 17 \\
Intact - Field & 10 & & 10 & & 10 & & 10 & & 4 \\
Ablated - Field & 10 & & 5 & & 1 & & 0 & 10 & 0 \\
Intact - Laboratory & 10 & & & & 10 & & 10 & 0 \\
Ablated - Laboratory & 10 & & & & 4 & & 1 & 0 \\
\hline
\end{tabular}

of the $P$. minor tested were dead after three days (Table 1).

Survival times of C. granulatus and $P$. assimilis placed in rotten wood and submerged were similar to those of beetles just immersed in water (Table 1). Unlike the $C$. granulatus and $P$. assimilis submerged in cold water in April those submerged in water at $22^{\circ} \mathrm{C}$ died within two and four days, respectively. That is, they survived for less than half the time when submerged at the higher temperature.

\section{Effects of elytra ablatement on $C$. granulatus survival}

C. granulatus with intact elytra survived longer than those with ablated elytra. In the field several intact individuals survived submergence for 17 days whereas none of the ablated individuals survived for longer than eight days (Table 2). Similar results were obtained under laboratory conditions with all the intact individuals surviving for 16 days and the ablated beetles no longer than 12 days (one individual).

\section{DISCUSSION}

During simulated flooding adult ground beetles trapped on the surface of the water were able to survive for nearly two weeks. Andersen (1968) records that some species of the genus Bembidion can survive on the surface of cold water $\left(6-8^{\circ} \mathrm{C}\right)$ for $50-80$ days and on warm water $\left(18-20^{\circ} \mathrm{C}\right)$ for no longer than 10 days. In both studies, death is likely to have resulted from trapped beetles starving to death rather than from "drowning". It is also likely that during flooding, individuals would swim until they encountered a surface onto which they could climb. Indeed, shore-dwelling species are able to orient to the nearest bank by reacting to the contrast between the bank and the sky (Jenkins, 1960; Lehmann, 1965). Thus, if beetles are able to float to the surface they are unlikely to die as a result of flooding.

However, adults of a number of carabids and closelyrelated tiger beetles (Brust \& Hoback, 2009) spend periods of inactivity in terrestrial burrows and may be caught by rising flood waters. These beetles may either be trapped in submerged air pockets or they may become completely immersed. In this study, most beetles trapped in a simulated air pocket survived for more than 9 but less than 12 days. Survival of flooding by insects in air pockets has been previously investigated for rove beetles, termites and mangrove ants. Intertidal species, such as Bledius spectabilis (Coleoptera: Staphylinidae), prevent their burrows from being flooded by blocking the entrance with mud. In these conditions the burrows become hypoxic in about four hours, whereas flooded burrows became anaerobic in about eight minutes (Wyatt, 1986). The time for which the subterranean termite, Reticulitermes flavipes (Isoptera: Rhinotermitidae) survives immersion in water is 3.4 times less than that of individuals trapped in air pockets within the gallery system (Forschler \& Henderson, 1995). Mangrove ants avoid immersion by using their heads to plug their burrows during high tides and switch to anaerobic metabolism in response to burrow hypoxia (Nielson \& Christian, 2007).

In our experiments, $C$. granulatus survived for a shorter period of time when trapped in air pockets (13 days) than when they were immersed with intact elytra in water (12 and 17 days, Table 2). Although reasons for these differences have not been determined, movement of adults while in air pockets could deplete metabolic reserves more quickly. Alternatively, the diffusion gradient from the air trapped in the chamber to the water surface may cause oxygen to be depleted and not replaced as is the case with a physical gill over a short distance. If the latter explanation is correct, beetles trapped in air-filled chambers may be more susceptible to immersion mortality than those submerged in water.

Differential survival of intact and ablated C. granulatus suggests that submerged adults are capable of storing air under their elytra and that this air reserve may act as a physical gill, prolonging survival (Vlasblom, 1970; Gilbert, 1986; Kehl \& Dettner, 2009). Survival using a physical gill would be influenced by water flow because flood waters in a floodplain become severely hypoxic unless water movement is maintained (Baumgartl et al., 1994). In this experiment, replacement of the water in the laboratory and flowing river water in the field appear to have been sufficient at low temperatures to allow survival of intact ground beetles. In contrast, Brust \& Hoback (2009) record that survival of adult Cicindela in severely hypoxic water, which simulates the conditions on a submerged floodplain, is generally positively correlated with beetle size. Their data suggest that tiger beetles also use the oxygen in their subelytral cavities during submersion and that adult survival times are likely to be greater if the beetles are submerged in aerated water. Hoback et al. (1998) found that survival of Cicindela larvae did not differ between aerated and severely anoxic water suggesting that these larvae cannot trap air that serves as a physical gill. The use of trapped air as a physical gill has 
been previously documented for the intertidal aphid, Pemphigus trehernei. When this species is flooded with aerated sea water, air bubbles are trapped between the appendages and the abdominal wax tufts and survival times of $P$. trehernei are 10 times greater in aerated water than in hypoxic sea water (Foster \& Treherne, 1976).

When insects are trapped in severely hypoxic water, they respond by depressing metabolism and by utilizing anaerobic metabolic pathways (Hoback et al., 2000, 2002). Increases in water temperature greatly reduce survival times for most species tested (Hoback et al., 1998; Brust \& Hoback, 2009). C. granulatus and P. assimilis submerged in warm water $\left(22^{\circ} \mathrm{C}\right)$ survived between two and three days, while in cold water $\left(5^{\circ} \mathrm{C}\right)$ they survived for 12 and 10 days, respectively. Andersen (1968) and Decleer (2003) record that adults of these ground beetles from the temperate zones can survive complete submergence in cold water $\left(4-6^{\circ} \mathrm{C}\right)$ for approximately 10 days. After 10 days of submergence at $4^{\circ} \mathrm{C}$ only $15 \%$ of the $C$. granulatus were still alive (Decleer, 2003). The results of our experiments revealed that all the $C$. granulatus tested were able to survive 10 days of submergence at $6-11^{\circ} \mathrm{C}$ (Table 1). These differences may be a result of differences in the amount of dissolved oxygen in the water or in the season of the year in which these studies were done. Our study, conducted in mid spring when beetles are not very active may allow enhanced survival because of greater metabolic reserves while Decleer (2003) tested the same species in late spring when the metabolic reserves may have been depleted.

In caterpillars, Neptis rivularis (Lepidoptera: Nymphalidae), which have a generally high metabolism and soft bodies, through which it is potentially possible for oxygen to diffuse, submergence for up to 21 days results in substantial mortality. However, in this case, there were no differences between aerated and anoxic conditions and mortality seems to be caused by failure of the osmotic balance (Konvička et al., 2002).

To our knowledge the effect of feeding status on the time individuals can survive immersion in water has not been tested. Such a test could aid in the explanation of differential survival among tests and among individuals.

Survival times of ground beetles during summer floods were low and usually no more than three days (Table 1). Zerm \& Adis (2001) reports that adult tiger beetles (Phaeoxantha klugii, P. lindemannae and Tetracha spinosa) inhabiting Central Amazonian floodplains can survive being submerged during flooding for no more than $10 \mathrm{~h}$ whereas the larvae of this species can survive for 3.5 months. In our study, most individuals of most species died within the first $24 \mathrm{~h}$. Although it is tempting to predict a correlation between survival time and the frequency and severity of floods, such correlations are not consistently found. For example, Hoback et al. (2002) report immersion survival among tiger beetle larvae to be correlated with immersion risk in two genera, while Brust \& Hoback (2009) record little agreement between immersion survival and habitat conditions for larvae and adults of 6 species of Cicindela. In this study, the highest sur- vival times were recorded for meso-hydrophilic, eurytopic $C$. granulatus and $P$. assimilis, $50 \%$ of which were still alive after three days. However, survival of mesoxerophilic $A$. fulva and meso-hydrophilic O. obscurus sharply decreased after one day (Table 1).

In autumn, different percentages of survival during flooding were recorded for the different species (Table 1). In September, all individuals of the mesophilic species $P$. aethiops were alive after three days of submergence however, none of the meso-hydrophilic $P$. atrorufus survived more than one day. It is likely that this difference is associated with ecological features of the species (humidity preference) and other characteristics of their life cycles. In August, only $C$. granulatus and $P$. assimilis tend to concentrate at overwintering sites. The individuals used in this study were collected from under bark and in decayed wood and were in a quiescent state. In contrast, autumn breeding species such as A. fulva are at the peak of their activity. Likewise, spring breeding $P$. aethiops sampled from hibernating sites were more resistant to submergence than autumn breeding $P$. atrorufus, which were active and reproducing (Table 1).

Survival times for all the species tested increased from August to November (Table 1) although there were differences among species. At the end of October, all individuals of the meso-hydrophilic $C$. granulatus and $P$. assimilis, and the hydrophilic $B$. dentellum tested survived nine days of submergence. In contrast, only $50 \%$ of the individuals of the meso-hydrophilic O. obscurus survived six days of submergence. The most sensitive species was the hydrophilic $P$. minor with only $50 \%$ surviving three days of submergence. This once again shows that ecological features do not completely account for the differences in species survival, which appear to be affected by a mixture of external and internal factors.

The results of these studies broaden the understanding of how flood plain insects survive flooding. Adults can survive long periods on the surface of the water and are able to orient to objects and climb out of the water. Adults that are quiescent, either in chambers or under litter, may become immersed. These individuals can survive relatively long periods when environmental temperatures are low and water flow is maintained. In some cases individuals prolong survival by trapping air bubbles and then using these air bubbles as a physical gill. When individuals are active and become immersed in flood water during summer they are only likely to survive for a short period. Thus, summer floods are likely to deplete the number of individuals in the area, which would then be re-colonized. In situations where humans alter the natural flood cycle by damming and controlled releases for irrigation or hydropower, adaptations for surviving flooding may not be sufficient to prevent extirpation or extinction as noted for some North American tiger beetles (Brust et al., 2005).

ACKNOWLEDGMENTS. We are grateful to the authorities of the reserve "Bryansky Les" for permission to collect beetles, K. Makarov and A. Matalin for advice and help with the experimental design and P. Povalinsky for help with the English. 


\section{REFERENCES}

AdIS J. 1982: Eco-entomological observations from the Amazon: II. Carabids are adapted to inundation-forests! Coleopt. Bull. 36: 439-440.

ADIS J. 1986: An "aquatic" millipede from a Central Amazonian inundation forest. Oecologia (Berlin) 68: 347-349.

Amorim M.A., Adis J. \& PAArman W. 1997: Ecology and adaptations of the tiger beetle Pentacomia egregia (Chaudoir) (Cicindelinae: Carabidae) to Central Amazonian floodplains. Ecotropica 3: 71-82.

ANDERSEN J.M. 1968: The effect of inundation and choice of hibernation sites of Coleoptera living on river banks. Norsk Entomol. Tidsskr. 15: 115-133.

ANDERSEN J.M. 2005: Riparian beetles, a unique, but vulnerable element in the fauna of Fennoscandia. Biodiv. Conserv. 14: 3497-3524.

Baumgartl H., Kritzler K., Zimelka W. \& Zinkler D. 1994 Local $\mathrm{PO}_{2}$ measurements in the environment of submerged soil microarthropods. Acta Oecol. 15: 781-789.

Brust M.L. \& Hoback W.W. 2009: Hypoxia tolerance in adult and larval Cicindela tiger beetles varies by life history but not habitat association. Ann. Entomol. Soc. Am. 102: 462-466.

Brust M.L., Hoback W.W., Skinner K.F. \& Knisley C.B. 2005: Differential immersion survival by populations of Cicindela hirticollis (Coleoptera: Cicindelidae). Ann. Entomol. Soc. Am. 98: 973-979.

Brust M.L., Hoback W.W., Skinner K.F. \& Knisley C.B. 2006: Movement of Cicindela hirticollis Say larvae in response to moisture and flooding. J. Insect Behav. 19: 251-263.

DeCleER K. 2003: Population dynamics of marshland spiders and carabid beetles due to flooding: about drowning, air bubbling, floating, climbing and re-colonization. In: Proc. Int. Conference "Towards Natural Flood Reduction Strategies", Warsaw, 3-13 September, 2003. pp. 1-6.

Forschler B. \& Henderson G. 1995: Subterranean termite behavioral reaction to water and survival of inundation: implications for field populations. Environ. Entomol. 24: 1592-1597.

Foster W.A. \& TREhERnE J.E. 1976: The effects of tidal submergence on an intertidal aphid, Pemphigus trehernei Foster. J. Anim. Ecol. 45: 291-301.

GILBeRT M. 1986: The respiratory system and respiratory technique of Hydroporus palustris (L.) (Coleoptera. Dytiscidae). Entomol. Basil. 11: 43-65.

Hoback W.W. \& Stanley D.W. 2001: Insects in hypoxia. $J$. Insect Physiol. 47: 533-542.

Hoback W.W., Stanley D.W., Higley L.G. \& Barnhart M.C. 1998: Survival of immersion and anoxia by larval tiger beetles, Cicindela togata. Am. Midl. Nat. 140: 27-33.

Hoback W.W., Podrabsky J.E., Higley L.G., Stanley D.W. \& HAND S.C. 2000: Anoxia tolerance of con-familiar tiger beetle larvae is associated with differences in energy flow and anaerobiosis. J. Comp. Physiol. 170: 307-314.

Hoback W.W., Clark T.L, Meinke L.J., Higley L.G. \& SCALZitTI J.M. 2002: Immersion survival differs among three Diabrotica species. Entomol. Exp. Appl. 105: 29-34.
Hochachka P.W., Nener J.C., Hoar J., Saures R.K. \& Hand S.C. 1993: Disconnecting metabolism from adenylate control during extreme oxygen limitation. Can. J. Zool. 71: $1267-1270$.

IRMLER U. 1979: Abundance fluctuations and habitat changes of soil beetles in Central Amazonian inundation forests (Coleoptera: Carabidae, Staphylinidae). Stud. Neotrop. Fauna Environ. 14: 1-16.

JENKINS M.F. 1960: On the method by which Stenus and Dianous (Coleoptera, Staphylinidae) return to the banks of a pool. Trans. R. Entomol. Soc. Lond. 112: 1-14.

Kehl S. \& Dettner K. 2009: Surviving submerged-setal tracheal gills for gas exchange in adult rheophilic diving beetles. J. Morphol. 270: 1348-1355.

KONVIČKA M., NEDVĚD O. \& FRIC Z. 2002: Early-spring floods decrease the survival of hibernating larvae of a wetlandinhabiting population of Neptis kivularis (Lepidoptera: Nymphalidae). Acta Zool. Acad. Sci. Hungar. 48: 79-88.

LeHMANN H. 1965: Ökologische Untersuchungen über die Carabidenfauna des Rheinufers in der Umgebung von Köln. Z. Morph. Ökol. Tiere 55: 597-630.

Nielsen M.G. \& Christian K.A. 2007: The mangrove ant, Camponotus andersoni, switches to anaerobic respiration in response to elevated $\mathrm{CO}_{2}$ levels. J. Insect Physiol. 53: 505-508.

ТАмм J.C. 1984: Surviving long submergence in the egg stage a successful strategy of terrestrial arthropods living on flood plains (Collembola, Acari, Diptera). Oecologia (Berlin) 61: 417-419.

TАмм J.C. 1986: Temperature-controlled under-water dormancy and postflood hatching in Isotoma viridis (Collembola) as forms of adaptation to annual long-term flooding. Oecologia (Berlin) 68: 241-245.

Vlasblom A.G. 1970: The respiratory significance of the physical gill in some adults insects. Comp. Biochem. Physiol. 36: $377-385$.

WeGENER G. 1993: Hypoxia and post hyoxic recovery in insects: physiological and metabolic aspects. In Hochachka P.W., Lutz P.L., Rosental M., Sick T. \& van den Thillart G. (eds): Surviving Hypoxia - Mechanisms of Control and Adaptation. CRC Press, Boca Raton, FL, pp. 417-432.

Wyatt T.D. 1986: How a subsocial intertidal beetle, Bledius spectabilis, prevents flooding and anoxia in its burrow. Behav. Ecol. Sociobiol. 19: 323-331.

ZeRM M. \& AdIS J. 2001: Further observations on the natural history and survavival strategies of riverine tiger beetles (Coleoptera: Cicindelidae) from open habitats in central Amazonian floodplains (Brazil). Ecotropica 7: 115-137.

Zerm M., Walenciak O., Val A.L. \& Adis J. 2004: Evidence for anaerobic metabolism in the larval tiger beetle, Phaeoxantha klugii (Col. Cicindelidae) from a Central Amazonian floodplain (Brazil). Physiol. Entomol. 29: 483-488.

Received May 19, 2011; revised and accepted September 23, 2011 